[報文］

\title{
Effects of gamma irradiation on the emergence of larvae of Curculio sikkimensis (Heller) (Coleoptera: Curculionidae) and Cydia kurokoi (Amsel) (Lepidoptera: Tortricidae)
}

\author{
Taro IMAMURA, Setsuko TODORIKI, Akihiro MIYANOSHITA and Toru HAYASHI \\ National Food Research Institute, 2-1-12 Kannondai, Tsukuba, Ibaraki 305-8642, Japan
ガンマ線照射によるクリシギゾウムシ（Curculio sikkimensis (Heller)
(Coleoptera: Curculionidae)) とクリミガ (Cydia kurokoi (Amsel)
(Lepidoptera: Tortricidae)）の幼虫の防除 \\ 今村太郎，等々力節子，宮八下明大，林 徹 \\ 独立行政法人 食品総合研究所（テ 305-8642 荻城県つくば市観音台 2-1-12）
}

\begin{abstract}
Summary
The effects of gamma irradiation on the emergence of larvae of the chestnut weevil, Curculio sikkimensis (Heller), were investigated. One hundred chestnuts were irradiated in a ${ }^{60} \mathrm{Co}$ irradiator (Gammacell 220, Nordion, Canada) at a dose rate of $0.40 \mathrm{kGy} / \mathrm{h}$. The doses at which irradiation was carried out were 50, 100, 200, 300, 400, 500 and $1000 \mathrm{~Gy}$. After treatment, the chestnuts were kept at $25^{\circ} \mathrm{C}, 70 \% \mathrm{RH}$ and emerged larvae were counted daily. Larvae of the nut fruit moth, Cydia kurokoi (Amsel), also emerged from the chestnuts. The data on the chestnut weevil were subjected to probit analysis and the LD 99.9 of weevil larvae was estimated to be about $500 \mathrm{~Gy}$.
\end{abstract}

\section{Introduction}

The chestnut weevil, Curculio sikkimensis (Heller) (Coleoptera: Curculionidae), is distributed over Japan, Korea and Russia. This weevil is a major pest of chestnuts in Japan. Female weevils oviposit into chestnut seeds before the chestnut seeds are havested. The larvae grow within the seeds from which they emerge as last-instar larvae. The larvae cause damage to the quality of the chestnuts (Fig. 1).

The control of the chestnut weevil has up to now been dependent on fumigation of harvested chestnuts with methyl bromide. However, the usage of methyl bromide is to be phased out by 2005 in developed countries for most purposes due to its ozone layer depleting effects. Hence, development of an alternative method is urgently needed. Irradiation by gamma rays is thought to be a safe and residue-free alternative. Numerous researcher have studied the efficacy of gamma irradiation on other weevils, such as the maize weevil (Sitophilus zeamais Motschulsky), the rice weevil (S. oryzae (L.)) and the granary weevil (S. granarius $(\mathrm{L} .)^{1)-3)}$. We predicted that gamma irradiation would effectively disinfest chestnuts contaminated with chestnut weevil larvae.

This paper reports on the effects of gamma irradiation on the emergence of chestnut weevil 

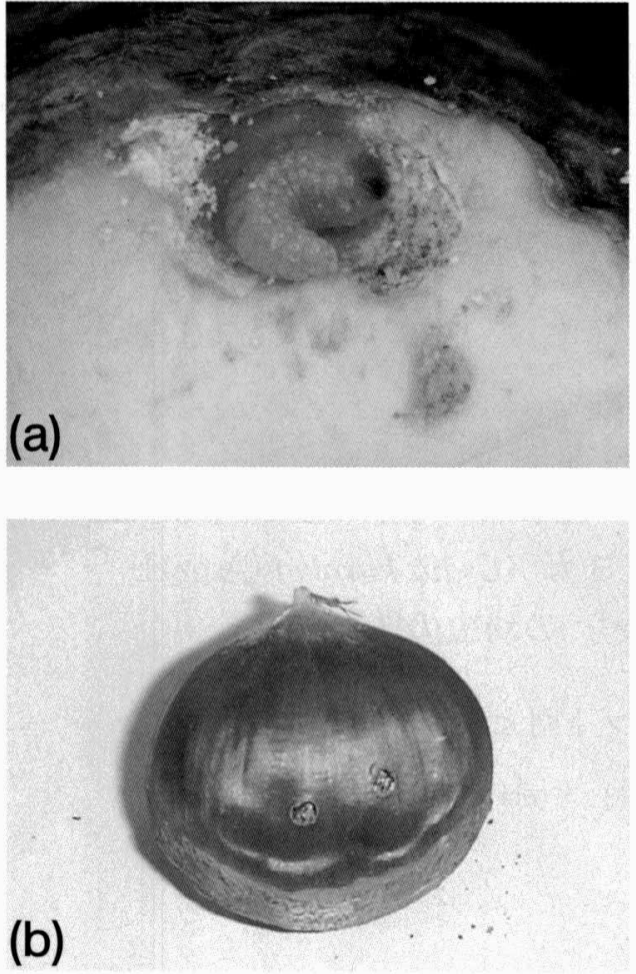

Fig. 1 Damage to chestnuts by chestnut weevils: (a) Chestnut weevil larva within a chestnut; (b) Chestnut with holes made by chestnut weevil larvae.

larvae from chestnut seeds.

\section{Materials and Methods}

Chestnuts (variety 'Tsukuba') were harvested on 30 September 2002 in Ibaraki prefecture. Treatments were carried out on 2 and 3 October. One hundred chestnuts were irradiated in a ${ }^{60} \mathrm{Co}$ irradiator (Gammacell 220, Nordion, Canada) at a dose rate of $0.40 \mathrm{kGy} / \mathrm{h}$. The doses were 50, 100, 200, 300, 400, 500 and 1000 Gy. After treatment, the chestnuts were kept at $25{ }^{\circ} \mathrm{C}, 70 \% \mathrm{RH}$, and emerged larvae were counted daily. Treatments were replicated 3 times.

The data were subjected to probit analysis ${ }^{4)}$ using the maximum likelihood method ${ }^{5)}$.

\section{Results and Discussion}

Table 1 shows the number of emerged larvae from 100 chestnuts. Larvae of the nut fruit moth, Cydia kurokoi (Amsel) (Lepidoptera: Tortricidae), also emerged from the chestnuts. The number of emerged weevil larvae decreased with increasing dose, and no larvae emerged from chestnuts irradiated at doses of $400 \mathrm{~Gy}$ and higher. The number of emerged larvae of $C$. kurokoi also decreased with increasing dose, and no larvae emerged from chestnuts irradiated at doses of $300 \mathrm{~Gy}$ and higher, although few larvae emerged even from the untreated control.

The LD99.9 of the chestnut weevil larvae was estimated by probit analysis to be $497 \mathrm{~Gy}$, so gamma irradiation would effectively disinfest chestnuts contaminated with chestnut weevil larvae at this dose. In this study, few larvae of $C$. kurokoi were observed, but this moth sometimes damages chestnuts more seriously than the chestnut weevil. Further research will be needed to estimate the LD99.9 of this moth.

\section{Acknowledgements}

This study was supported financially by the Budget of Nuclear Research of the Ministry of Education, Culture, Sports, Science and Technology, based on the screening and counseling by the Atomic Energy Commission.

\section{References}

1) Aldryhim Y. N. and Adam E. E.: Efficacy of

Table 1 The number of emerged larvae of $C$. sikkimensis and $C$. kurokoi (mean $\pm \mathrm{SE}$ ) from 100 chestnuts

\begin{tabular}{lrrrccccc}
\hline Dose (Gy) & \multicolumn{1}{c}{0} & \multicolumn{1}{c}{50} & \multicolumn{1}{c}{100} & 200 & 300 & 400 & 500 & 1000 \\
\hline C. sikkimensis & $55.0 \pm 6.5$ & $30.0 \pm 7.0$ & $20.7 \pm 1.9$ & $8.7 \pm 2.7$ & $0.7 \pm 0.7$ & 0 & 0 & 0 \\
C. kurokoi & $1.3 \pm 0.7$ & $2.3 \pm 0.7$ & $2.0 \pm 0.0$ & $0.3 \pm 0.3$ & 0 & 0 & 0 & 0 \\
\hline
\end{tabular}


gamma irradiation against Sitophilus granarius (L.) (Coleoptera: Curculionidae), J. Stored Prod. Res., 35, 225-232(1999).

2) Brown G. A. et al.: Gamma radiation effects on Sitophilus zeamais and S. granarius, J. Econ. Entomol., 65, 203-205 (1972).

3) Tilton E. W. et al.: Effects of gamma radiation on Rhyzopertha dominica, Sitophilus oryzae, Tribolium confusum and Lasioderma serricorne, J. Econ. Entomol., 59, 1393-1368(1966).

4) Finney D. L.: Probit Analysis, 3rd Edition, Cambridge University Press, Cambridge (1971).

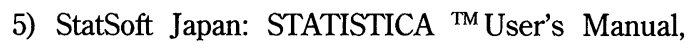
2nd Edition, StatSoft inc., Tokyo (in Japanese) (1999).

\section{和文要旨}

クリシギゾウムシ(Curculio sikkimensis (Heller))の 幼虫の出現に対するガンマ照射の影響を調査した。 ${ }^{60} \mathrm{Co}$ ガンマ線照射装置 (Gammacell 220, Nordion, カナダ）を用い， 100 個のクリを， $0.40 \mathrm{kGy} / \mathrm{h}$ の線 量率で, $50,100,200,300,400,500$ および $1000 \mathrm{~Gy}$ で照射した。照射処理後のクリは $25^{\circ} \mathrm{C}, 70 \% \mathrm{RH}$ で 貯蔵し, 果実から出現する幼虫を毎日計数した。同 時にクリミガ (Cydia kurokoi(Amsel)) に対する効 果も観察した。クリシギゾウムシ幼虫の生残データ をプロビット解析したところ, LD 99.9 は約 $500 \mathrm{~Gy}$ であると推測された。

(2004 年 7 月 6 日受理) 